\title{
Disruption of Retinoic Acid Receptor Signaling by Environmental Pollutants
}

\author{
Daisuke Inoue, ${ }^{*}$ Kazunari Sei, and Michihiko Ike \\ Division of Sustainable Energy and Environmental Engineering, Osaka University, 2-1 Yamadaoka, Suita, Osaka 565-0871, Japan
}

(Received December 16, 2009)

\begin{abstract}
Retinoic acid (RA) receptors (RARs) are nuclear receptors that play a critical role in regulating cellular proliferation, development and differentiation in vertebrates in response to endogenous RAs, i.e., all-trans RA and 9-cis RA. On the other hand, it has been well-known that both a deficiency and an excess of RA and related retinoids can cause a variety of teratogenic effects on developing embryos of vertebrates, which has been proven to be an RAR-mediated process. Therefore, the occurrence of xenobiotic environmental pollutants that interfere with RARs and disrupt the RAR signaling (i.e., show RAR agonistic or antagonistic effects) may pose a threat to the health of wild animals and humans. This review mainly focuses on RAR agonists. We summarize the RAR agonistic activity of natural and xenobiotic compounds determined using in vitro bioassay systems and present recent field research showing the occurrence of RAR agonist contamination in the aquatic environment in North America, China and Japan. Environmental pollution by RAR agonists is a new endocrine disruption issue discovered very recently, and relevant knowledge is very limited. Further research will be required to obtain accurate information to assess the possible risks of RAR agonists in the environment.
\end{abstract}

Key words_ retinoic acid, retinoic acid receptor, retinoic acid receptor agonist, environmental pollutants, aquatic environment

\section{INTRODUCTION}

Vitamin A (retinol) and its biologically active derivatives (collectively referred to as retinoids), most notably retinoic acids (RAs), exert their pleiotropic effects on cellular proliferation, development and differentiation in vertebrates. ${ }^{1-7)}$ Furthermore, they have suppressive effects on carcinogenesis in various tissue types (e.g., oral, skin, lung, liver, breast, bladder and prostate cancers). ${ }^{8,9)}$

Retinoids elicit their effects through binding to two major families of retinoid-responsive nuclear receptors, RA receptors (RARs) and retinoid X receptors (RXRs). ${ }^{5,6,10)}$ Both RAR and RXR contain three isotypes, $\alpha, \beta$ and $\gamma$, with numerous isoforms. ${ }^{5,6,8)}$ RARs are activated by all-trans RA (atRA) and 9-cis RA (9cRA), while RXRs are activated only by 9cRA. ${ }^{5,6,8)}$ The RAR/RXR het-

\footnotetext{
${ }^{*}$ To whom correspondence should be addressed: Division of Sustainable Energy and Environmental Engineering, Osaka University, 2-1 Yamadaoka, Suita, Osaka 565-0871, Japan. Tel.: +81-6-6879-7674; Fax: +81-6-6879-7675; E-mail: inoue@wb.see.eng.osaka-u.ac.jp
}

erodimer, where RAR binds to a ligand and RXR does not, is the most common functional unit that transduces the retinoid signal at the gene level (Fig. 1). ${ }^{11,12)}$ In the basal state, the RAR/RXR heterodimer is bound to nuclear receptor corepressor or silencing mediator of retinoid and thyroid receptors. ${ }^{13,14)}$ Binding of the ligand leads to the conformational change of the complex and allows the release of corepressors and recruitment of coactivators, which results in the transcriptional activation of target genes via specific RA response elements (Fig. 1). ${ }^{13,14)}$ Well-known target genes of retinoid receptors are the Hox genes, a family of homeoboxcontaining genes having an essential role in the specification of positional information in the developing embryo. ${ }^{16-18)}$ By regulating the expression of Hox genes, the retinoid receptors largely affect the normal morphogenesis in vertebrates.

Contrary to the biological functions, it has been confirmed during last several decades that both a deficiency and an excess of RAs and related retinoids can cause teratogenic effects on various vertebrates. In addition, recent studies have 


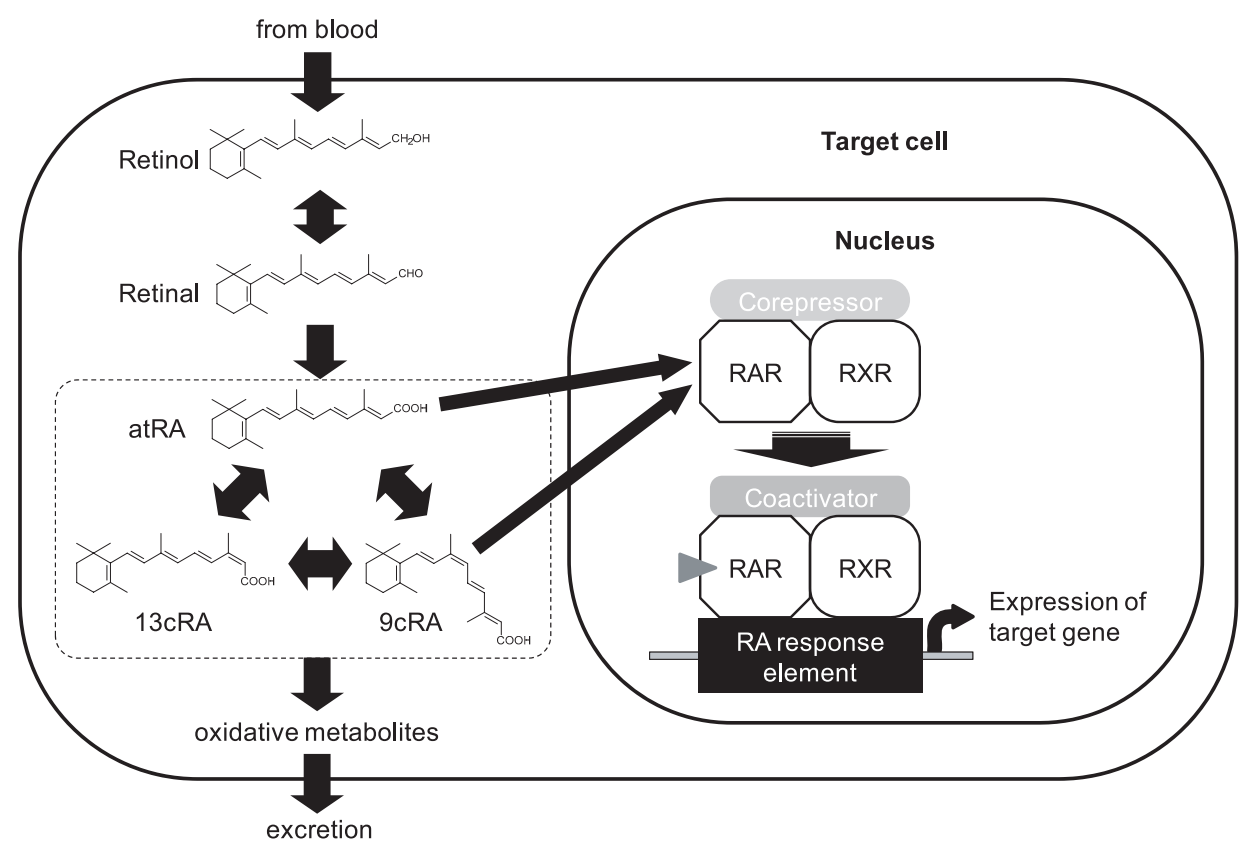

Fig. 1. Schematic Representation of the Metabolism of Retinoids and Activation of RAR Signaling in a Cell (Adapted from Refs. 13-15)).

shown that such RAR-mediated detrimental effects can occur or actually occur via environmental pollutants. Several reviews have recently summarized that some environmental pollutants (e.g., polychlorinated biphenyls, polychlorinated dibenzo- $p$ dioxins, polychlorinated dibenzofurans and polycyclic aromatic hydrocarbons) can interfere with retinoid transport, metabolism and signaling in wild animals, and consequently cause adverse health effects. ${ }^{14,15,19,20)}$ Furthermore, the presence of environmental pollutants, including those known and unknown, that have binding affinity to RAR and can directly disrupt RAR signaling through their RAR agonistic or antagonistic effects have been very recently confirmed by both laboratory experiments and field investigations. Based on the available evidence, the occurrence of RAR disrupting environmental pollutants has been recently recognized as a new endocrine disruption issue that results in detrimental effects on humans and wild animals.

This review focuses on the RAR agonists that can lead to excess RAR signaling. First, we make a brief summary concerning the biological effects on various animal species by excess RAR signaling. Then, we summarize the RAR agonistic potential of natural and xenobiotic compounds as determined in laboratory experiments and present recent field research that demonstrate the occurrence of RAR agonistic compounds in the aquatic environment.

\section{BIOLOGICAL EFFECTS BY EXCESS RAR SIGNALING}

While RAR signaling plays essential roles in the early development of vertebrates, ligands of RARs are also well-known potential teratogens in developing vertebrate embryos. Table 1 summarizes the abnormal morphological development in various animals induced by embryonic exposure to excess atRA, the natural and most potent RAR ligand. The type and degree of malformations induced differs depending largely on the species and timing (i.e., developmental stage), duration and dosage of atRA administration. However, chronic exposure to atRA at concentrations equal to hundreds of nanograms a liter or more can cause a wide variety of dysmorphogenesis in various tissues (e.g., eye, brain, limb and body axis) of fish, amphibians, birds, and mammals. Degitz et al. ${ }^{26)}$ reported that chronic exposure to atRA at as low as $600 \mathrm{ng} / \mathrm{l}$ for $3 \mathrm{~d}$ caused craniofacial deformities in Xenopus laevis embryos. In addition, it has been reported that ligands specific for each RAR isotype ( $\alpha, \beta$ or $\gamma$ ) induce specific deformities. RAR $\alpha$ ligands cause deformities of the ear, mandible and limb, RAR $\beta$ ligands cause defects of the urinary system and liver, and RAR $\gamma$ ligands cause ossification deficiencies and defects of the sternebrae and vertebral body. ${ }^{33-35)}$

Excess intake of retinoids can cause deleterious 
Table 1. Teratogenic Effects Caused by Exposure to atRA in Various Vertebrates

\begin{tabular}{|c|c|c|c|c|}
\hline Species & Dose $(\mu g / 1)$ & $\overline{\text { Exposure period }}$ & Observed biological effects & $\overline{\text { Ref. }}$ \\
\hline \multicolumn{5}{|l|}{ Fish } \\
\hline \multirow[t]{2}{*}{$\begin{array}{l}\text { Zebrafish (Daniol } \\
\text { Brachydanio rerio) }\end{array}$} & 0.9 & $\begin{array}{l}\text { From stage } 13 \text { (onset of epiboly) to } \\
\text { stage } 23\end{array}$ & $\begin{array}{l}\text { Oedema and deformities of brain (reduc- } \\
\text { tion or absence of ventricle of the telen- } \\
\text { cephalon) and tail (shortened and bent tail) }\end{array}$ & 21) \\
\hline & 90 & $\begin{array}{l}1 \mathrm{hr} \text { during late gastrulation }(90- \\
100 \% \text { epiboly) }\end{array}$ & Multiple pectoral fins & 22) \\
\hline \multirow[t]{4}{*}{$\begin{array}{l}\text { Japanese flounder (Par- } \\
\text { alichthys olivaceus) }\end{array}$} & $\begin{array}{c}3 \\
\text { (every day) }\end{array}$ & $10 \mathrm{~d}$ from premetamorphic period & Fin deformity & 23) \\
\hline & 7.5 & 6 to $9 \mathrm{~d}$ post-hatching & $\begin{array}{l}\text { Deformities of lower jaw (growth retarda- } \\
\text { tion of the dentary), caudal fin (deformity } \\
\text { of caudal bone complex and absence of en- } \\
\text { tire caudal fin) and vertebrae (central fu- } \\
\text { sion, hypertrophy of the centrum, and ad- } \\
\text { ditional abdominal vertebrae) }\end{array}$ & 24) \\
\hline & 15 & $\begin{array}{l}40 \mathrm{hr} \text { from hatching period }(2.5 \mathrm{~d} \\
\text { post-fertilization) }\end{array}$ & $\begin{array}{l}\text { Deformities in mandible, hyoid and gill } \\
\text { arches }\end{array}$ & 25) \\
\hline & 30 & $\begin{array}{l}1 \mathrm{hr} \text { at the shield stage }(26 \mathrm{hr} \text { post- } \\
\text { fertilization) }\end{array}$ & $\begin{array}{l}\text { Deformity of lower jaw (absence of the } \\
\text { Meckel's cartilage in mandible arch and fu- } \\
\text { sion of cartilages in mandible and hyoid } \\
\text { arches) }\end{array}$ & 25) \\
\hline \multicolumn{5}{|l|}{ Amphibian } \\
\hline \multirow[t]{3}{*}{$\begin{array}{l}\text { African clawed frogs } \\
\text { (Xenopus laevis) }\end{array}$} & 0.6 & $3 \mathrm{~d}$ from stage 8 to 41 & $\begin{array}{l}\text { Craniofacial deformity (microphthalmia, } \\
\text { reductions in the prosencephalon and mes- } \\
\text { encephalon, and oedema) }\end{array}$ & 26) \\
\hline & 6.25 & $\begin{array}{l}24 \text { hr from stage } 8 \text { (mid-blastula } \\
\text { stage) }\end{array}$ & $\begin{array}{l}\text { Microphthalmia and prosencephalic reduc- } \\
\text { tion }\end{array}$ & 27) \\
\hline & 500 & $\begin{array}{l}24 \text { hr from stage } 51 \text { (mid-limb bud } \\
\text { stage) }\end{array}$ & Hind-limb malformation & 27) \\
\hline $\begin{array}{l}\text { Mink frog (Rana } \\
\text { septentrionalis) }\end{array}$ & 6.25 & $\begin{array}{l}24 \mathrm{hr} \text { from stage } 8 \text { (mid-blastula } \\
\text { stage) }\end{array}$ & $\begin{array}{l}\text { Microphthalmia and prosencephalic reduc- } \\
\text { tion }\end{array}$ & 27) \\
\hline $\begin{array}{l}\text { Green frog (Rana } \\
\text { clamitans) }\end{array}$ & 25 & $\begin{array}{l}24 \mathrm{hr} \text { from stage } 8 \text { (mid-blastula } \\
\text { stage) }\end{array}$ & $\begin{array}{l}\text { Microphthalmia, prosencephalic reduction } \\
\text { and posterior dysmorphogenesis }\end{array}$ & 27) \\
\hline $\begin{array}{l}\text { Wood frog (Rana } \\
\text { sylvatica) }\end{array}$ & 500 & $\begin{array}{l}24 \mathrm{hr} \text { from stage } 28 \text { (mid-limb bud } \\
\text { stage) }\end{array}$ & Hind-limb malformation & 27) \\
\hline \multicolumn{5}{|l|}{ Bird } \\
\hline $\begin{array}{l}\text { White Leghorn (Gallus } \\
\text { gallus domesticus) }\end{array}$ & $\begin{array}{l}\text { Subblastodermal } \\
\text { injection of } 0.5 \mu \mathrm{g} \\
\text { per embryo }\end{array}$ & $\begin{array}{l}\text { HH stage } 13 \text { to early } 14 \text { (tail bud } \\
\text { anlagen stage) }\end{array}$ & Caudal axial malformation & 29) \\
\hline \multicolumn{5}{|l|}{ Mammal } \\
\hline \multirow[t]{2}{*}{ Sprague-Dawley rat } & 10 & $\begin{array}{l}46 \mathrm{hr} \text { from afternoon of } 9 \mathrm{~d} \text { post } \\
\text { gestation }\end{array}$ & Deformities in the second visceral arch & 30) \\
\hline & 150 & $48 \mathrm{hr}$ from $9.5 \mathrm{~d}$ post coitum & $\begin{array}{l}\text { Deformities in the branchial apparatus (hy- } \\
\text { poplasia of branchial arches and fusion of } \\
\text { first and second branchial arches) }\end{array}$ & 31) \\
\hline \multirow[t]{2}{*}{ Wistar-Imamichi rat } & 60 & $6 \mathrm{hr}$ from $9 \mathrm{~d}$ post coitum & $\begin{array}{l}\text { Reduction of the size of the first branchial } \\
\text { arch, microcephaly, abnormal eye pri- } \\
\text { mordium, and open neural tube }\end{array}$ & 32) \\
\hline & 60 & $6 \mathrm{hr}$ from $9.5 \mathrm{~d}$ post coitum & Branchial arch fusion and open neural tube & 32) \\
\hline
\end{tabular}


effects not only in wild animals but also in humans. Intake of large amounts of vitamin A (retinol) from supplements and use of RA congeners as therapeutic agents by pregnant women can increase the risk of birth defects on the central nervous system, ear, brain, heart, etc. ${ }^{36,37)}$

The available evidence on the biological effects resulted from the disruption of RAR signaling infers that the environmental occurrence of RA mimics that exhibit the RAR agonistic activity and disrupt the RAR signaling may cause detrimental effects in wild animals living in the polluted site. In addition, drinking water and eating food polluted with environmental RA mimics may increase the risk of disrupting the RAR signaling in humans that is normally caused by daily ingestion of vitamin A and RA congeners.

\section{NATURAL AND XENOBIOTIC COMPOUNDS THAT ACT AS RAR AGONISTS}

Besides RAs (natural RAR ligands), many endogenous compounds have been reported to be agonists of RAR. Oxidative metabolites of RA in humans and animals such as 4-oxo-RA, 4-hydroxyRA, 18-hydroxy-RA and 5,6-epoxy-RA can bind to RARs and activate the RAR-mediated transcription via an RA response element. ${ }^{28,38-40)}$ In particular, 4-oxo-RAs such as 4-oxo-atRA and 4-oxo-13-cis RA (4-oxo-13cRA) have been proven to have RAR agonistic activity equivalent to atRA using different in vitro bioassay systems. ${ }^{28,38,40)}$ Furthermore, numerous studies have demonstrated that these RA metabolites exhibit RAR-mediated biological activity just as RA does. ${ }^{28,41-45)}$

Recent studies have also revealed that xenobiotic environmental pollutants can elicit the binding affinity to and the agonistic activity on RARs. Xenobiotic compounds including not only wellknown endocrine disrupting chemicals (EDCs) such as alkylphenols, ${ }^{46-48)}$ phthalate esters, ${ }^{49)}$ styrene dimers $^{48)}$ and organochlorine pesticides ${ }^{50)}$ but also non-EDCs ${ }^{51)}$ have been proven to exhibit agonistic activity on one or several isotypes of RAR in vitro (Table 2). However, xenobiotic pollutants with agonistic activity at $\operatorname{RAR} \alpha$ are very limited as compared with those with $\operatorname{RAR} \beta$ or RAR $\gamma$ agonistic ability (Table 2). Kamata et al. ${ }^{48)}$ evaluated the RAR $\gamma$ agonistic activity of 543 compounds including industrial chemicals, agrochemicals, natu- ral compounds, medicines and cosmetic chemicals with a yeast two-hybrid assay, and revealed that 85 chemicals including 16 organochlorine pesticides, 14 styrene dimers, 9 alkylphenols and 6 parabens were active at $\operatorname{RAR} \gamma$ (showing $\geq 20 \%$ of RAR $\gamma$ agonistic activity of $10 \mathrm{nM}$ of atRA) at concentrations equal to $0.2-10 \mu \mathrm{M}$. Lemaire et al. ${ }^{50)}$ also reported that organochlorine pesticides having teratogenic activities in animals (i.e., aldrin, chlordane, dieldrin, endrin and endosulfan) weakly activate $\operatorname{RAR} \beta$ and $\operatorname{RAR} \gamma$ but do not activate RAR $\alpha$ in a transactivation assay, and that among these five pesticides, endrin is the most effective at both $\operatorname{RAR} \beta$ and $\operatorname{RAR} \gamma$ with $50 \%$ effective concentrations of $17.6 \mu \mathrm{M}(6.7 \mathrm{mg} / \mathrm{l})$ and $6.0 \mu \mathrm{M}(2.3 \mathrm{mg} / \mathrm{l})$, respectively. On the other hand, we revealed that telephthalic acid and linear dodecyl-benzensulfonate, both of which have not been regarded as EDCs, have binding affinity at $\operatorname{RAR} \gamma \cdot{ }^{51)}$

As shown in Table 2, RAR agonistic or binding activities of xenobiotic compounds reported to date are very low as compared with those of atRA. Therefore, these pollutants are not likely to disrupt RAR signaling and cause biological adverse effects at their normal environmental concentrations. However, some of xenobiotic compounds such as organochlorine pesticides are extremely persistent and tend to accumulate in biological tissues. Those compounds are further biomagnified in the food chain. Thus, despite their low RAR agonistic potencies, RAR-mediated biological effects might be possible if exposed to such a high level of xenobiotic compounds during the embryogenesis.

\section{FINDINGS OF RAR AGONIST CONTAMINATION IN THE AQUATIC ENVIRONMENT}

Despite the very low potency of currently known RAR agonistic environmental pollutants, several recent studies have detected a significant RAR agonistic activity in North America and China (Table 3). In some examples, adverse effects on aquatic animals probably caused by the RAR agonists that occur in the environment have also been observed.

Gardiner et al. ${ }^{55)}$ first detected RAR agonistic activity in the natural aquatic environment. They investigated the occurrence of RAR $\alpha$ agonistic activity in two widely separated sites in the U.S.A. (a permanent lake in Minnesota and a vernal pond 
Table 2. Representative Xenobiotic Compounds with RAR Binding/Agonistic Potency

\begin{tabular}{|c|c|c|c|}
\hline Compound & RAR type & Binding/agonistic potency (assay system) $^{a)}$ & Ref. \\
\hline \multirow[t]{3}{*}{ 4-Nonylphenol } & $\operatorname{RAR} \alpha, \beta, \gamma$ & Weak activation (yeast two-hybrid assay) & 46) \\
\hline & $\operatorname{RAR} \gamma$ & $0.01-0.1 \%$ of atRA (CoA-BAP assay) & 47) \\
\hline & $\operatorname{RAR} \gamma$ & $0.476 \%$ of atRA (yeast two-hybrid assay) & 48) \\
\hline \multirow[t]{3}{*}{ 4-t-Octylphenol } & $\operatorname{RAR} \alpha, \beta, \gamma$ & Weak activation (yeast two-hybrid assay) & 46) \\
\hline & $\operatorname{RAR} \gamma$ & $0.01-0.1 \%$ of atRA (CoA-BAP assay) & 47) \\
\hline & $\operatorname{RAR} \gamma$ & $0.997 \%$ of atRA (yeast two-hybrid assay) & 48) \\
\hline 2-Chloro-4-octylphenol & $\operatorname{RAR} \gamma$ & $1.286 \%$ of atRA (yeast two-hybrid assay) & 48) \\
\hline 2,6-Dichloro-4-octylphenol & $\operatorname{RAR} \gamma$ & $1.041 \%$ of atRA (yeast two-hybrid assay) & 48) \\
\hline 4-t-Butylphenol & $\operatorname{RAR} \alpha, \beta, \gamma$ & Weak activation (yeast two-hybrid assay) & 46) \\
\hline 2-t-Butylphenol & $\operatorname{RAR} \alpha, \beta, \gamma$ & Weak activation (yeast two-hybrid assay) & 46) \\
\hline 4-n-Heptylphenol & $\operatorname{RAR} \gamma$ & $1.363 \%$ of atRA (yeast two-hybrid assay) & 48) \\
\hline Benzophenone & $\operatorname{RAR} \gamma$ & $0.1-1 \%$ of atRA (CoA-BAP assay) & 47) \\
\hline \multirow[t]{2}{*}{ Hexachlorocyclohexane } & $\operatorname{RAR} \gamma$ & $0.1-1 \%$ of atRA (CoA-BAP assay) & 47) \\
\hline & RAR $\gamma$ & $0.668 \%$ of atRA (yeast two-hybrid assay) & 48) \\
\hline 1-Phenyltetralin & $\operatorname{RAR} \gamma$ & $1.169 \%$ of atRA (yeast two-hybrid assay) & 48) \\
\hline Mono(2-ethylhexyl)phthalate & RAR from human prostate & $\begin{array}{l}\text { Inhibition binding constant of } 407 \mathrm{nM} \\
\text { (competitive binding assay) }\end{array}$ & 49) \\
\hline Telephthalic acid & $\operatorname{RAR} \gamma$ & $0.001-0.1 \%$ of atRA (CoA-BAP assay) & $51)$ \\
\hline Linear dodecyl-benzensulfonate & $\operatorname{RAR} \gamma$ & $0.001-0.1 \%$ of atRA (CoA-BAP assay) & $51)$ \\
\hline Aldrin & $\operatorname{RAR} \beta, \gamma$ & Weak activation (transactivation assay) & $50)$ \\
\hline Chlordane & $\operatorname{RAR} \beta, \gamma$ & Weak activation (transactivation assay) & $50)$ \\
\hline Dieldrin & $\operatorname{RAR} \beta, \gamma$ & Weak activation (transactivation assay) & $50)$ \\
\hline Endrin & $\operatorname{RAR} \beta, \gamma$ & $\begin{array}{c}\mathrm{EC} 50^{b)} \text { of } 17.6 \pm 3.4 \mu \mathrm{M} \text { and } 6.0 \pm 0.8 \mu \mathrm{M} \text { for } \mathrm{RAR} \beta \\
\text { and RAR } \gamma, \text { respectively (transactivation assay) }\end{array}$ & $50)$ \\
\hline Endosulfan & $\operatorname{RAR} \beta, \gamma$ & Weak activation (transactivation assay) & $50)$ \\
\hline
\end{tabular}

Table 3. RAR Agonist Contamination Detected in Different Countries

\begin{tabular}{llll}
\hline \hline Country & \multicolumn{1}{c}{ Location or sample } & Causative compounds & Ref. \\
\hline U.S.A. & $\begin{array}{l}\text { - A permanent lake in Minnesota and a vernal pond in Califor- } \\
\text { nia, where malformed frogs were frequently observed }\end{array}$ & Unidentified & 55) \\
Canada & - Effluent from 11 pulp mills & Unidentified & 39) \\
China & - Influent and effluent from 7 wastewater treatment plants & 4-Oxo-atRA and 4-oxo-13cRA & 40) \\
& (WWTPs) receiving mainly domestic wastewater & & \\
& - Surface water from Tonghui River and Qing River in Beijing & & 56, 57) \\
Japan & - Surface water from 4 rivers in the Kinki region & Unidentified & 58, 59) \\
& - Influent and effluent from 7 municipal WWTPs in Osaka Pre- & Unidentified & \\
& fecture and 3 municipal WWTPs in Toyama Prefecture & & \\
\hline
\end{tabular}

in California) where deformed frogs had been frequently discovered. Consequently, a high response of RAR $\alpha$ agonistic activity was detected commonly in both sites. ${ }^{55)}$ From the results in this study and another study, Gardiner and co-workers suggest that the occurrence of environmental pollutant(s) acting as RAR agonists, which were named "environmen- tal retinoid(s)," is the most probable cause of the outbreak of deformed frogs that occurred in the upper Midwest U.S.A. and Canada. ${ }^{55,60)}$

In another study by Alsop et al., ${ }^{39)}$ to clarify the cause of dramatic reductions of stored hepatic retinoids observed in adult male and female white suckers (Catostomus commersoni) in the Mattagami 
River in northeastern Ontario (Canada) receiving the bleached kraft mill effluent, the methanol and dichloromethane extracts from the effluent of pulp mills across Canada were examined for their binding to rainbow trout (Oncorhynchus mykiss) RARs from the gill. Competitive binding assays from their study demonstrated that the final effluent from several tested mills exhibited the ability to displace $\left[{ }^{3} \mathrm{H}\right]$ atRA from the gill RAR in a dose-dependent manner.

A few years after the findings that reported the occurrence of RAR agonists in North America, a detailed survey on RAR agonist contamination was performed in Beijing, China by our research group because adverse effects such as curved tail tip and reduction of hatching success rate had been observed on Japanese medaka (Oryzias latipes) embryos exposed to the secondary effluent from a wastewater treatment plant (WWTP). We investigated the RAR $\alpha$ agonistic activity in seven WWTPs and their receiving rivers (Tonghui River and Qing River) and detected a significant activity mainly in the ethyl acetate fraction (medium polar fraction) of the wastewater and water samples. ${ }^{40)}$ The maximal atRA equivalents (atRA-EQ) in the fraction estimated based on the results of yeast two-hybrid assay were 13.4, 3.2 and $10.0 \mathrm{ng} / \mathrm{l}$ in WWTP influent, WWTP effluent and river water, respectively, which were much lower than the atRA concentration exhibiting teratogenic effects in animals (Table 1). Most of the $\operatorname{RAR} \alpha$ agonistic activity detected in river water seemed to be explained by WWTP effluents and untreated wastewater discharged from several wastewater discharging pipes. However, unexpectedly high activities obtained in the upstream of the Qing River suggested the presence of unknown significant sources.

Causative compounds for the RAR agonist contamination have not been identified in the studies performed in North America (Table 3). ${ }^{39,55)}$ However, results in these studies suggest the presence of multiple RAR agonists in aquatic samples. ${ }^{39,55)}$ In addition, Gardiner et al. ${ }^{55)}$ suggest from the characteristics of their study sites that the causative RAR agonists for frog malformations are not natural in origin. By contrast, our study in Beijing, China succeeded in identifying the major RAR agonists present in sewage as 4-oxo-atRA and 4-oxo-13cRA (Table 3). ${ }^{40)}$ 4Oxo-atRA and 4-oxo-13cRA are generated in human and animal bodies by the metabolism of RAs and are eliminated from the bodies through urinary excretion mainly as glucuronide conjugates (retinoyl- $\beta$-glucuronides). ${ }^{13,34,61,62)}$ Thus, it is likely that 4-oxo-atRA and 4-oxo-13cRA are reproduced through the deconjugation of their glucuronides in the sewage system and WWTPs. Because the concentrations of both 4-oxo-RAs were largely reduced from influent to effluent irrespective of the WWTP, ${ }^{40)}$ these compounds appear to be easily removable from the water phase through the degradation by activated sludge microorganisms and/or the adsorption onto activated sludge flocs in WWTPs. In addition, we also suggested the presence of other unidentified RAR agonists in the river water because 4-oxo-RAs could not account for the total RAR agonistic activity in samples upstream from the WWTP on the Qing River. ${ }^{40)}$ Based on the currently available evidence, multiple unknown RAR agonists seem to exist in the aquatic environment.

\section{ENVIRONMENTAL POLLUTION BY RAR AGONISTS IN JAPAN}

Environmental pollution by RAR agonists occurs not only in foreign countries but also in Japan (Table 3). Our recent studies in 4 rivers in the Kinki region and in several WWTPs in Osaka and Toyama Prefectures detected statistically significant RAR $\alpha$ agonistic activity commonly in surface waters in all of the investigated rivers ${ }^{56,57)}$ and influents and effluents from the WWTPs. ${ }^{58,59)}$ River water pollution by RAR agonists occurs irrespective of the pollution level of the rivers, and surprisingly even in the upstream suburban areas with little human activity. ${ }^{56,57)}$ In addition, strong RAR $\alpha$ agonistic activity unaccountable by the activity of WWTP effluents was detected in river water samples. ${ }^{56,57,59)}$ Therefore, WWTPs do not seem to be the major source of RAR agonists in our study areas in Japan, which is different from the RAR agonist pollution found in Beijing, China as described above. Also, simultaneous investigation of the agonistic activities at $\operatorname{RAR} \alpha$ and estrogen receptor $\alpha$ suggests that the variation along the watercourse of RAR agonist pollution in Japanese rivers is completely dissimilar to that of the estrogenic contamination, a widely known EDCs problem. ${ }^{56,57)} \mathrm{Al}$ though the RAR agonists present in aquatic samples in Japan are not yet identified (Table 3), the river pollution level in the Kinki region of Japan appears to be greater than that in Beijing, China. ${ }^{40,57)}$ 
However, the maximal atRA-EQ in river water was estimated to be $47.6 \mathrm{ng} / 1,{ }^{57}$ ) which was more than 10 -fold lower than the atRA level leading to the abnormal morphological developments in vertebrates (Table 1). Therefore, the level of RAR agonist pollution is not likely to cause RAR-mediated deleterious biological effects at present.

\section{CONCLUSIONS}

In this review, we have presented the recent evidence regarding RAR agonist contamination in the aquatic environment. Although the potency of known RAR agonistic xenobiotic compounds is very low, pollution of the aquatic environment by RAR agonists has been recently observed in widely separated countries (North America, China and Japan). These findings suggest that the environmental pollution by RAR agonists occurs widely in the aquatic environment. In addition, the study in North America ${ }^{55)}$ demonstrates that unidentified RAR agonists present in the environment can really threaten the health of wild animals by disrupting their RAR signaling. Therefore, further studies, particularly the identification of unknown RAR agonists and the investigation of the occurrence and fates of both already-known and unknown RAR agonists present in the aquatic environment, are needed to understand the overall picture of the environmental pollution with RAR agonists. Studies concerning the toxicity of those RAR agonists occurred in the aquatic environment, e.g. determination of their agonistic activities on RARs of different animal species and evaluation of the correlation between the RAR agonistic activity obtained from in vitro bioassays and the toxicity in vivo, should be also carried out to assess the possible ecological risks resulted from the RAR agonist pollution.

Acknowledgements The authors thank Dr. Tsuyoshi Nakanishi of the Laboratory of Hygienic Chemistry and Molecular Toxicology, Gifu Pharmaceutical University, for his valuable and stimulating discussions. This study was supported in part by the FY2008 Environmental Technology Development Fund of the Ministry of the Environment, Japan, and the Grant-in-Aid for Young Scientists (B) 20760362 from the Ministry of Education, Culture, Sports, Science and Technology, Japan.

\section{REFERENCES}

1) Lohnes, D., Mark, M., Mendelsohn, C., Dollé, P., Dierich, A., Gorry, P., Gansmuller, A. and Chambon, P. (1994) Function of the retinoic acid receptors (RARs) during development. (I) Craniofacial and skeletal abnormalities in RAR double mutants. Development, 120, 2723-2748.

2) Mendelsohn, C., Lohnes, D., Décimo, D., Lufkin, T., LeMeur, M., Chambon, P. and Mark, M. (1994) Function of the retinoic acid receptors (RARs) during development. (II) Multiple abnormalities at various stage of organogenesis in RAR double mutants. Development, 120, 2749-2771.

3) Sporn, M., Roberts, A. and Goodman, D. (1994) The Retinoids: Biology, chemistry, and medicine, Raven Press, New York.

4) Kastner, P., Mark, M. and Chambon, P. (1995) Nonsteroid nuclear receptors: what are genetic studies telling us about their role in real life? Cell, 83, 859869.

5) Sucov, H. M. and Evans, R. M. (1995) Retinoic acid and retinoic acid receptors in development. Mol. Neurobiol., 10, 169-184.

6) Chambon, P. (1996) A decade of molecular biology of retinoic acid receptors. FASEB J., 10, 940-954.

7) Zile, M. H. (2001) Function of vitamin A in vertebrate embryonic development. J. Nutr., 131, 705708.

8) Sun, S.-Y. and Lotan, R. (2002) Retinoids and their receptors in cancer development and chemoprevention. Crit. Rev. Oncol. Hematol., 41, 41-55.

9) Clarke, N., Germain, P., Altucci, L. and Gronemeyer, H. (2004) Retinoids: potential in cancer prevention and therapy. Expert Rev. Mol. Med., 6, 1-23.

10) Blumberg, B. (1997) An essential role for retinoid signaling in anteroposterior neural specification and neuronal differentiation. Semin. Cell. Dev. Biol., 8, 417-428.

11) Mangelsdorf, D. J., Thummel, C., Beato, M., Herrlich, P., Schütz, G., Umesono, K., Blumberg, B., Kastner, P., Mark, M., Chambon, P. and Evans, R. M. (1995) The nuclear receptor superfamily: The second decade. Cell, 83, 835-839.

12) Kastner, P., Mark, M., Ghyselinck, N., Krezel, W., Dupé, V., Grondona, J. M. and Chambon, P. (1997) Genetic evidence that the retinoid signal is transduced by heterodimeric RXR/RAR functional units during mouse development. Development, 124, 313-326.

13) Marill, J., Idres, N., Capron, C. C., Nguyen, E. and Chabot, G. G. (2003) Retinoic acid metabolism and 
mechanism of action: a review. Curr. Drug Metab., 4, 1-10.

14) Novák, J., Beníšek, M. and Hilscherová, K. (2008) Disruption of retinoid transport, metabolism and signaling by environmental pollutants. Environ. Int., 34, 898-913.

15) Simms, W. and Ross, P. S. (2000) Vitamin A physiology and its application as a biomarker of contaminant-related toxicity in mammals: a review. Toxicol. Ind. Health, 16, 291-302.

16) Marshall, H., Morrison, A., Studer, M., Pöpperl, H. and Krumlauf, R. (1996) Retinoids and Hox genes. FASEB J., 10, 969-978.

17) Daftary, G. S. and Taylor, H. S. (2006) Endocrine regulation of HOX genes. Endocr. Rev., 27, 331355.

18) Glover, J. C., Renaud, J.-S. and Rijli, F. M. (2006) Retinoic acid and hindbrain patterning. J. Neurobiol., 66, 705-725.

19) Rolland, R. M. (2000) A review of chemicallyinduced alterations in thyroid and vitamin A status from field studies of wildlife and fish. J. Wildl. Dis., 36, 615-635.

20) Janošek, J., Hilscherová, K., Bláha, L. and Holoubek, I. (2006) Environmental xenobiotics and nuclear receptors-Interactions, effects and in vitro assessment. Toxicol. in Vitro, 20, 18-37.

21) Herrmann, K. (1995) Teratogenic effects of retinoic acid and related substances on the early development of the zebrafish (Brachydanio rerio) as assessed by a novel scoring system. Toxicol. in Vitro, 9, 267-283.

22) Vandersea, M. W., Fleming, P., McCarthy, R. A. and Smith, D. G. (1998) Fin duplications and deletions induced by disruption of retinoic acid signaling. Dev. Genes Evol., 208, 61-68.

23) Miwa, S. and Yamano, K. (1999) Retinoic acid stimulates development of adult-type chromatophores in the flounder. J. Exp. Zool., 284, 317-324.

24) Haga, Y., Suzuki, T. and Takeuchi, T. (2002) Retinoic acid isomers produce malformations in postembryonic development of the Japanese flounder, Paralichthys olivaceus. Zool. Sci., 19, 11051112.

25) Suzuki, T., Srivastava, A. S. and Kurokawa, T. (2000) Experimental induction of jaw, gill and pectoral fin malformations in Japanese flounder, Paralichthys olivaceus, larvae. Aquaculture, 185, 175187.

26) Degitz, S. J., Holcombe, G. W., Kosian, P. A., Tietge, J. E., Durhan, E. J. and Ankley, G. T. (2003) Comparing the effects of stage and duration of retinoic acid exposure on amphibian limb devel- opment: chronic exposure results in mortality, not limb malformations. Toxicol. Sci., 74, 139-146.

27) Degitz, S. J., Kosian, P. A., Makynen, E. A., Jensen, K. M. and Ankley, G. T. (2000) Stage- and speciesspecific developmental toxicity of all-trans retinoic acid in four native North American Ranids and Xenopus laevis. Toxicol. Sci., 57, 264-274.

28) Pijnappel, W. W. M., Hendriks, H. F. J., Folkers, G. E., van den Brink, C. E., Dekker, E. J., Edelenbosch, C., van der Saag, P. T. and Durston, A. J. (1993) The retinoid ligand 4-oxo-retinoic acid is a highly active modulator of positional specification. Nature, $\mathbf{3 6 6}$, 340-344.

29) Griffith, C. M. and Wiley, M. J. (1991) Effects of retinoic acid on chick tail bud development. Teratology, 43, 217-224.

30) Ritchie, H. E., Brown-Woodman, P. D. and Korabelnikoff, A. (2003) Effect of co-administration of retinoids on rat embryo development in vitro. Birth Defects Res. A Clin. Mol. Teratol., 67, 444451.

31) Menegola, E., Broccia, M. L., Di Renzo, F., Massa, V. and Giavini, E. (2004) Relationship between hindbrain segmentation, neural crest cell migration and branchial arch abnormalities in rat embryos exposed to fluconazole and retinoic acid in vitro. Reprod. Toxicol., 18, 121-130.

32) Lee, Y. M., Osumi-Yamashita, N., Ninomiya, Y., Moon, C. K., Eriksson, U. and Eto, K. (1995) Retinoic acid stage-dependently alters the migration pattern and identity of hindbrain neural crest cells. Development, 121, 825-837.

33) Elmazar, M. M. A., Reichert, U., Shroot, B. and Nau, H. (1996) Pattern of retinoid-induced teratogenic effects: possible relationship with relative selectivity for nuclear retinoid receptors $\operatorname{RAR} \alpha$, RAR $\beta$, and RAR $\gamma$. Teratology, 53, 158-167.

34) Collins, M. D. and Mao, G. E. (1999) Teratology of retinoids. Annu. Rev. Pharmacol. Toxicol., 39, 399430.

35) Elmazar, M. M. A., Rühl, R. and Nau, H. (2001) Synergistic teratogenic effects induced by retinoids in mice by coadministration of a $\operatorname{RAR} \alpha$ - or $\operatorname{RAR} \gamma$ selective agonist with a RXR-selective agonist. Toxicol. Appl. Pharmacol., 170, 2-9.

36) Rosa, F. W., Wilk, A. L. and Kelsey, F. O. (1986) Teratogen updates: Vitamin A congeners. Teratology, 33, 355-364.

37) Rothman, K. J., Moore, L. L., Singer, M. R., Nguyen, U.-S. D. T., Mannino, S. and Milunsky, A. (1995) Teratogenicity of high vitamin A intake. $N$. Engl. J. Med., 333, 1369-1373.

38) Idres, N., Marill, J., Flexor, M. A. and Chabot, 
G. G. (2002) Activation of retinoic acid receptordependent transcription by all-trans-retinoic acid metabolites and isomers. J. Biol. Chem., 277, 31491-31498.

39) Alsop, D., Hewitt, M., Kohli, M., Brown, S. and van der Kraak, G. (2003) Constituents within pulp mill effluent deplete retinoid stores in white sucker and bind to rainbow trout retinoic acid receptors and retinoid X receptors. Environ. Toxicol. Chem., 22, 2969-2976.

40) Zhen, H., Wu, X., Hu, J., Xiao, Y., Yang, M., Hirotsuji, J., Nishikawa, J., Nakanishi, T. and Ike, M. (2009) Identification of retinoic acid receptor agonists in sewage treatment plants. Environ. Sci. Technol., 43, 6611-6616.

41) Reynolds, N. J., Fisher, G. J., Griffiths, C. E. M., Tavakkol, A., Talwar, H. S., Rowse, P. E., Hamilton, T. A. and Voorhees, J. J. (1993) Retinoic acid metabolites exhibit biological activity in human keratinocytes, mouse melanoma cells and hairless mouse skin in vivo. J. Pharmacol. Exp. Ther, 266, 1636-1642.

42) Nikawa, T., Schulz, W. A., van den Brink, C. E., Hanusch, M., van der Saag, P., Stahl, W. and Sies, H. (1995) Efficacy of all-trans- $\beta$-carotene, canthaxanthin, and all-trans-, 9-cis-, and 4-oxoretinoic acids in inducing differentiation of an F9 embryonal carcinoma RAR $\beta$-lacZ reporter cell line. Arch. Biochem. Biophys., 316, 665-672.

43) Gaemers, I. C., van Pelt, A. M. M., van der Saag, P. T. and de Rooij, D. G. (1996) All-trans-4-oxoretinoic acid: a potent inducer of in vivo proliferation of growth-arrested A spermatogonia in the vitamin A-deficient mouse testis. Endocrinology, 137, 479-485.

44) Van der Leede, B. M., van den Brink, C. E., Pijnappel, W. W. M., Sonneveld, E., van der Saag, P. T. and van der Burg, B. (1997) Autoinduction of retinoic acid metabolism to polar derivatives with decreased biological activity in retinoic acidsensitive, but not in retinoic acid-resistant human breast cancer cells. J. Biol. Chem., 272, 1792117928.

45) Van Heusden, J., Wouters, W., Ramaekers, F. C. S., Krekels, M. D. W. G., Dillen, L., Borgers, M. and Smets, G. (1998) All-trans-retinoic acid metabolites significantly inhibit the proliferation of MCF-7 human breast cancer cells in vitro. Br. J. Cancer, 77, 26-32.

46) Nishikawa, J., Mamiya, S., Kanayama, T. and Nishihara, T. (2003) Effect of suspected endocrine disruptors on various kinds of nuclear hormone receptors. Journal of Environmental Biotechnology, 3,
37-42 (in Japanese).

47) Kanayama, T., Kobayashi, N., Mamiya, S., Nakanishi, T. and Nishikawa, J. (2005) Organotin compounds promote adipocyte differentiation as agonists of the peroxisome proliferator-activated receptor $\gamma /$ retinoid X receptor pathway. Mol. Pharmacol., 67, 766-774.

48) Kamata, R., Shiraishi, F., Nishikawa, J., Yonemoto, J. and Shiraishi, H. (2008) Screening and detection of in vitro agonistic activity of xenobiotics on the retinoic acid receptor. Toxicol. in Vitro, 22, 1050 1061.

49) Pagnetto, G., Campi, F., Varani, K., Piffanelli, A., Giovannini, G. and Borea, P. A. (2000) Endocrinedisrupting agents on healthy human tissues. Pharmacol. Toxicol., 86, 24-29.

50) Lemaire, G., Balaguer, P., Michel, S. and Rahmani, R. (2005) Activation of retinoic acid receptor-dependent transcription by organochlorine pesticides. Toxicol. Appl. Pharmacol., 202, 38-49.

51) Inoue, D., Matsui, H., Sei, K., Yang, M., Hu, J., Aragane, J., Hirotsuji, J., Nishikawa, J. and Ike, M. (2007) Binding affinity of PRTR chemicals to various human nuclear receptors. Journal of Japan Society on Water Environment, 30, 89-94 (in Japanese).

52) Åström, A., Pettersson, U., Krust, A., Chambon, P. and Voorhees, J. J. (1990) Retinoic acid and synthetic analogs differentially activate retinoic acid receptor dependent transcription. Biochem. Biophys. Res. Commun., 173, 339-345.

53) Beard, R. L., Chandraratna, R. A. S., Colon, D. F., Gillett, S. J., Henry, E., Marler, D. K., Song, T., Denys, L., Garst, M. E., Arefieg, T., Klein, E., Gil, D. W., Wheeler, L., Kochhar, D. M. and Davies, P. J. A. (1995) Synthesis and structure-activity relationships of stilbene retinoid analogs substituted with heteroaromatic carboxylic acids. J. Med. Chem., 38, 2820-2829.

54) Pignatello, M. A., Kauffman, F. C. and Levin, A. A. (1999) Multiple factors contribute to the toxicity of the aromatic retinoid TTNPB (Ro 13-7410): interactions with the retinoic acid receptors. Toxicol. Appl. Pharmacol., 159, 109-116.

55) Gardiner, D., Ndayibagira, A., Grün, F. and Blumberg, B. (2003) Deformed frogs and environmental retinoids. Pure Appl. Chem., 75, 2263-2273.

56) Inoue, D., Nakama, K., Matsui, H., Sei, K. and Ike, M. (2009) Detection of agonistic activities against five human nuclear receptors in river environments of Japan using a yeast two-hybrid assay. Bull. Environ. Contam. Toxicol., 82, 399-404.

57) Inoue, D., Nakama, K., Sawada, K., Watanabe, T., Takagi, M., Sei, K., Yang, M., Hirotsuji, J., Hu, 
J., Nishikawa, J., Nakanishi, T. and Ike, M. (2010) Contamination with retinoic acid receptor agonists in two rivers in the Kinki region of Japan. Water Res., in press.

58) Inoue, D., Matsui, H., Sei, K., Hu, J., Yang, M., Aragane, J., Hirotsuji, J. and Ike, M. (2009) Evaluation of effectiveness of chemical and physical sewage treatment technologies for removal of retinoic acid receptor agonistic activity detected in sewage effluent. Water Sci. Technol., 59, 24472453.

59) Inoue, D., Nakama, K., Watanabe, T., Sawada, K., Matsui, H., Sei, K., Nakanishi, T. and Ike, M. (2009) Screening of multiple nuclear receptor agonistic activities in wastewater treatment plants in Japan using yeast two-hybrid assay. Proceedings of the 2nd IWA Asia-Pacific Young Water Professionals Conference, 200-206.

60) Gardiner, D. M. and Hoppe, D. M. (1999) Environmentally induced limb malformations in mink frogs (Rana septentrionalis). J. Exp. Zool., 284, 207-216.

61) Li, S., Barua, A. B. and Huselton, C. A. (1996) Quantification of retinoyl- $\beta$-glucuronides in rat urine by reversed-phase high-performance liquid chromatography with ultraviolet detection. J. Chromatogr. B: Biomed. Sci. Appl., 683, 155-162.

62) Barua, A. B. (1997) Retinoyl $\beta$-glucuronide: a biologically active form of vitamin A. Nutr. Rev., 55, 259-267. 